inOfedia $\quad \begin{aligned} & \text { InMedia } \\ & \text { The French Journal of Media Studies }\end{aligned}$

9.1. $\mid 2021$

Film and TV-induced Tourism: Some Contemporary

Aspects and Perspectives

\title{
The Séries Mania festival and its impact on the Hauts-de-France territory
}

An interview with Karina Hocquette, education and audiencedevelopment manager for the Séries Mania festival

Laëtitia Garcia

\section{CpenEdition}

Electronic version

URL: https://journals.openedition.org/inmedia/3047

DOI: 10.4000/inmedia.3047

ISSN: 2259-4728

Publisher

Center for Research on the English-Speaking World (CREW)

Electronic reference

Laëtitia Garcia, "The Séries Mania festival and its impact on the Hauts-de-France territory", InMedia

[Online], 9.1. | 2021, Online since 15 January 2022, connection on 08 February 2022. URL: http:// journals.openedition.org/inmedia/3047 ; DOl: https://doi.org/10.4000/inmedia.3047

This text was automatically generated on 8 February 2022.

(C) InMedia 


\section{The Séries Mania festival and its impact on the Hauts-de-France territory}

An interview with Karina Hocquette, education and audiencedevelopment manager for the Séries Mania festival

\section{Laëtitia Garcia}

1 The Séries Mania festival was created by the city of Paris and was first held at the Parisian Forum des Images in 2010 with Laurence Herszberg at its head. The French government, however, wanted to create an international festival dedicated to television series that would be on a par with the Cannes film festival. The French authorities therefore decided to issue a call, in association with the CNC (Centre National du Cinema), for host cities to present their strategy for the festival's organization. ${ }^{1}$ The project presented by the city of Lille and defended by an alliance of different political partners was among five selected for the final race and won in 2017, notably thanks to its structural advantages, discussed in the present interview. ${ }^{2}$ Lille then bought the Séries Mania trademark from the city of Paris, and the capital city of the Hauts-de-France region has been hosting the festival since 2018 under the leadership of Laurence Herszberg, who chose to stay at its helm. There have now been four Séries Mania editions in Lille, and the present interview highlights how the festival has developed and examines its impact on the Hauts-de France region as it has boosted local, French, and border-crossing tourism to the area.

Laëtitia Garcia: Has the festival attendance grown over the past two years?

The festival attendance has been growing year after year, and for example we noticed a 23\% increase between the 2018 and the 2019 editions, the latter gathering more than 72,000 spectators. We can accurately measure the attendance at the various festival locations (in auditoriums and at the Village Festival sponsored by the Crédit Mutuel) thanks to our hostesses there who daily count the ticket sales. As to the 'off' events, we know about their attendance thanks to their organizing structures. 


\section{LG: What is the geographical origin of the festival-goers?}

The geographical origin of our festival-goers is predominantly local. During the 2019 edition, 79\% of them came from the Hauts-de-France area. However, the festival has been attracting a growing number of visitors from outside our region. The percentage of those visitors thus went from 15\% in 2018 to $21 \%$ in 2019.

LG: Have you thus implemented a strategy to diversify your audience and to successfully attract more visitors from outside the Hauts-de-France territory?

In the short term, the aim of the festival is to develop nationally and later on internationally. Currently, the Séries Mania team is working hard on developing both its cross-border (with Belgium - editor's note) and national audiences.

The festival is carrying out several actions to reach out to more people from outside the Hauts-de-France territory. For example, the festival has forged links with the French national education system. News about the festival are thus directly forwarded throughout the country to all the different regional school inspectors in charge of the audiovisual part of the French curriculum. They act as the festival's communication relays at the national level, and make it possible to reach out to many school children and their teachers beyond our regional territory. At national level, the festival is thus developing numerous partnerships with all the people in charge of the audiovisual part of the French curriculum.

The festival also tries to reach out to the Parisian audience [in fact its original audience as the festival was created in Paris in 2010, before moving to Lille in 2018 editor's note]. We have thus developed several communication actions specifically targeting the Ile-de-France region. For example, in 2020 a billboard advertising campaign was carried out in the Parisian metro, trailers were shown in our UGC partner's cinemas, Séries Mania-labelled place mats adorned the tables of Parisian bars and cafés...

As Parisians live only one hour away from Lille thanks to the TGV (the French highspeed train - editor's note), we targeted them via a communication campaign carried out in partnership with the national French railway company. During the 2019 festival period, the company's customers were thus offered rather cheap Paris-Lille return tickets that included entrance to Séries Mania events.

Our festival aims to be a benchmark festival that is both demanding and at the same time accessible to everyone. Its audience development strategy notably relies on actions carried out throughout the year and that entail numerous partnerships with associative structures. The festival's programming intends to grow and extend further afield to the different French regions.

Séries Mania is not currently undertaking any specific action for the development of its international audience. It is still a budding festival gradually working on developing its attendance. Catching the eye of international audiences will be part of its development strategy in the years to come.

LG: Do you resort to any specific means of communication to attract visitors from beyond the Hauts-de-France territory?

Poster-based advertising represents an important part of the festival's communication. So locally this led to advertising via billboards throughout Lille city 
centre and the entire Lille metropolis, thanks to the support of the city council and the MEL (Métropole Européenne de Lille) that let us use their public display systems.

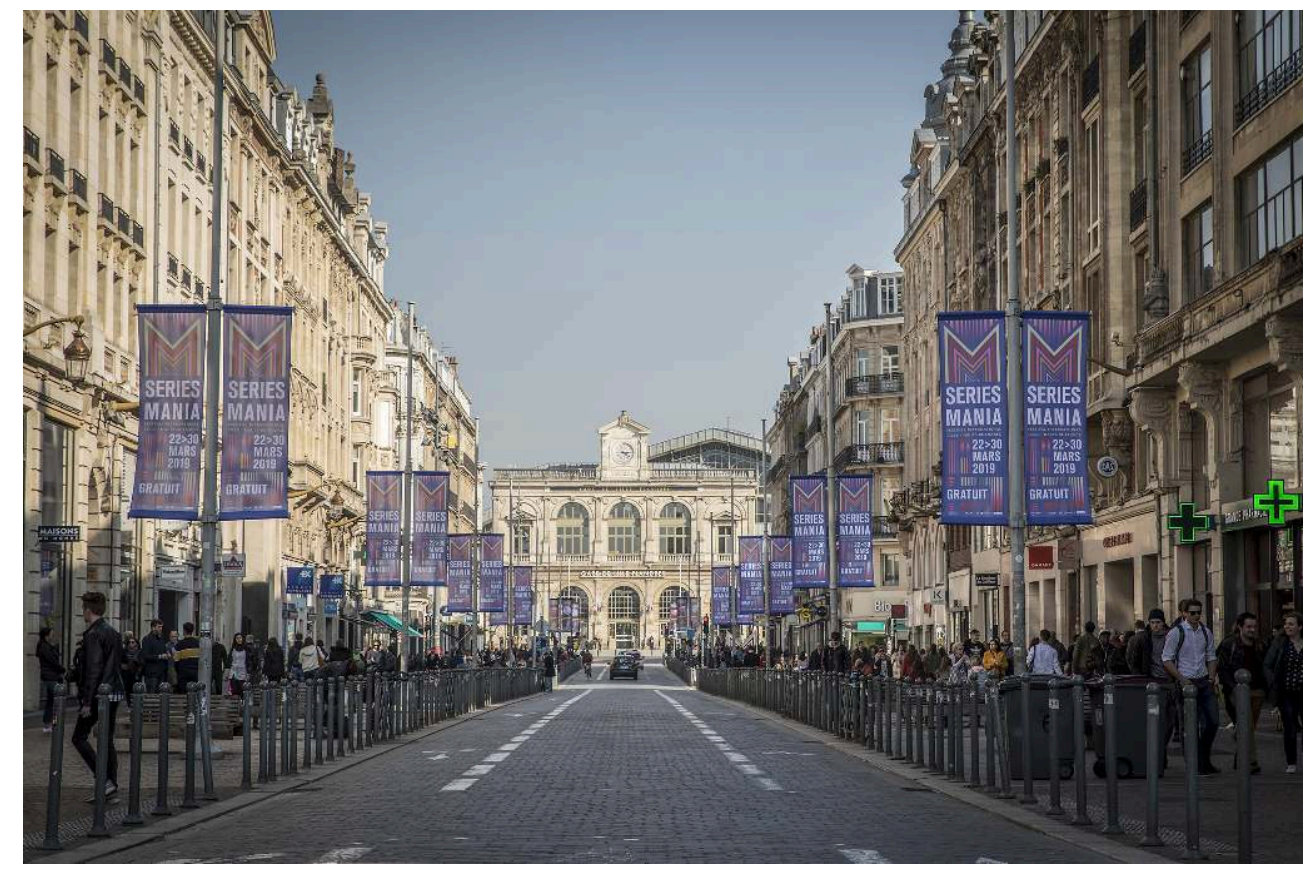

Fig.1: Séries Mania Flags on the Rue Faidherbe in Lille, 2019

(C) Jonathan Lelong - Séries Mania

But at a more international level, we also presented Séries Mania during the Are You Series? festival at the Palais des Beaux-Arts (BOZAR) in Brussels as part of the preparation for the 2018 edition, which allowed Séries Mania to be known to different categories of Belgian professionals.

As for France, apart from Lille and its area, the festival notably targets the Ile-deFrance territory with the advertising campaign previously mentioned (billboards in the metro, trailers in partner cinemas, place mats on Parisian bar, tables, etc.).

To reach a wider audience, the festival is particularly focused on digital development by strengthening its social network footprint and creating new content for its website. We also rely on social media influencers. For example, during the 2019 edition, the festival invited 15 social media influencers from Lille and 5 from Paris to discover Séries Mania and report on it.

For its 2021 edition, the festival, in parallel with its on-site physical version, will offer a digital platform intended to advertise the festival at the national and international levels. This will enable more distant audiences to discover the festival and perhaps make them want to come here and experience its Lille on-site version.

LG: A festival, through its ability to create / shape the image of a territory, can be a driving force for the latter's development by attracting new visitors. Do you think Séries Mania is helping to change the image of the Hauts-de-France territory?

The Séries Mania festival is a large-scale event for the French audiovisual sector, especially in the field of TV series. It is a festival that generates a significant level of excitement and which, without any doubt, contributes to give a young, modern and dynamic image to the Hauts-de-France territory. According to the 2019 survey 
carried out by the Hauts-de-France chamber of commerce, ${ }^{3}$ respondents repeatedly used terms such as "innovative", "surprising" and "magical" to describe what they thought of the festival. This of course helps to convey a dynamic and attractive image of the Hauts-de-France territory.

LG: Have you tried to quantify the economic impact of the festival on its home territory?

The festival has had a significant economic impact on the Hauts-de-France territory. The economic benefits of the 2019 edition were estimated at $€ 5,273,063$ (which included more than $€ 2,200,000$ spent by festival goers).

LG: Which parts of the festival have the biggest impact on where people come from? For example, do you think programming plays a part in this?

Yes, programming can play a part, of course. The screenings of big events are always the first ones to be fully booked out. But it is also a discovery festival whose objective is to present a panorama of the best international ${ }^{4}$ audiovisual creations which also attract a large audience every year. However, we currently do not look at where people come from for each screening, and therefore we cannot measure the impact of programming on audiences. Further analysis is nevertheless planned for the festival's future editions.

LG: You are bound to work in direct partnership with the towns/cities hosting Séries Manialinked events. Are you involved in the analysis of their territorial attractive potential and the way the festival may contribute to it?

There are information meetings organized for the town councils in each city/town hosting Séries Mania-linked events. The local councillors are in fact our first contacts and help us identify the possible locations that could welcome the festival audiences. We work with all the involved council services, including the communication departments. Town and cities then spread the word to the local population. We also work with urban development and conurbation committees. These different partnerships are essential and played an important part in the sharp $43 \%$ increase in attendance at regional screenings in 2019. For example, the screening of the Mytho series in Dunkirk gathered a large audience thanks to a partnership between Séries Mania and Dunkirk's urban development committee, the latter having actively communicated on this event.

LG: Does the festival's choice of regional sites contribute to the promotion of the Hauts-deFrance's historical heritage? Is it a planned policy?

The goal of the Séries Mania festival is to attract people's attention while its being held. When we meet with town councils, we try to identify several possible locations, and during previous editions we chose to programme events on sites highlighting the heritage of our territory.

The Wallers-Arenberg disused coal mine (located south-east of Lille), now a museum and a UNESCO World Heritage Site, was thus selected to host an event during the 2020 Séries Mania edition. Some events and meetings of that edition were also due to take place in several of Lille's emblematic places like the Théâtre du Nord (now a listed building), Lille's Chamber of Commerce and the Prefecture's reception rooms. (Most of those events were cancelled because of the Covid-19 pandemic.) 
LG: When choosing your locations, do you try to make some urban sites more touristfriendly?

As said before, the festival aims to be held in easy-to-access and central locations, which does not however preclude unusual ones. For example, during the 2018 edition, a discovery tour, followed by a concert, were organized in La Madeleine's Mary Magdalene's Church that is normally closed to the public. The festival's "off" events allow us to choose more varied locations, sometimes further away from city centres, and to reach out to other local town and cities that are different from those hosting Séries Mania main events.

LG: Are the dates of the festival chosen in agreement with the actors of the territory and as part of a tourism planning strategy?

It is important for us to fit within the cultural calendar of our territory and our city, in particular with regard to the latter's major cultural events such as Lille3000, but also to its other events that attract many national and foreign visitors (such as trade fairs that require a large hotel room capacity). This is why we always work in partnership with Lille's Tourist Information Centre and Congress Centre.

We are also in contact with other major French and international audiovisual festivals (such as Cannes, Berlin, La Rochelle, London, Singapore, etc.) and work around their calendars. And when the closing ceremony of our festival once took place at the same time as the opening ceremony of the Video Mapping festival, we then worked in direct partnership with them to set up a joint event. This led to the screening of a TV series-themed Video Mapping Festival event on the façade of Lille's opera, thus allowing for the mixing of both festivals' audiences (Fig.2).

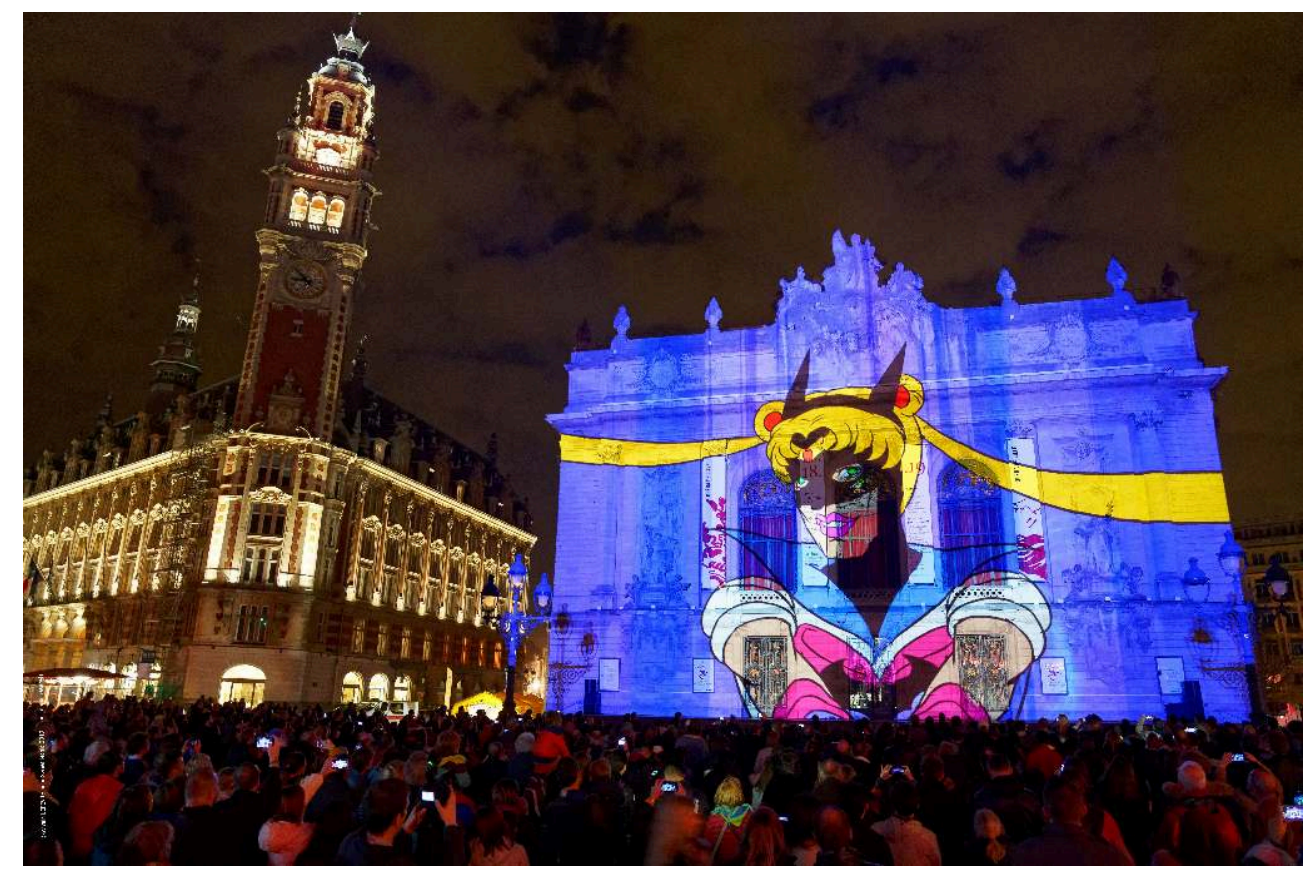

Fig. 2: TV series-themed Video Mapping Festival event on the façade of Lille's opera, OFF Mapping festival, 2019

(c) Sylvain Lefevre - Séries Mania 


\section{NOTES}

1. Enrique Moreira, "Fleur Pellerin veut un festival international des séries télé," Les Échos, December 16, 2015. https://www.lesechos.fr/2015/12/fleur-pellerin-veut-un-festivalinternational-des-series-tele-285409\# <accessed on January 9, 2022>.

2. The others were Bordeaux, Cannes, Nice and Paris. Aurélien Ferenczi, "Laurence Herszberg quitte Séries Mania pour Lille: 'J'espère qu'à terme il n'y aura qu'un festival'," Télérama, July 6, 2017. https://www.telerama.fr/series-tv/laurence-herszberg-quitte-series-mania-pour-lille-jespere-qu-a-terme-il-n-y-aura-qu-un-festival,160471.php <accessed on January 9, 2022>.

3. The CCI Hauts-de-France survey was conducted via an emailed questionnaire to participants of the Séries Mania Forum

4. The 2020 edition was to include events from 30 countries.

\section{AUTHOR}

\section{LAËTITIA GARCIA}

Dr Laëtitia Garcia is Senior Lecturer in the field of Management Sciences at the University of Lille since 2006, member of the CRDP (research center on laws and perspectives of the law). She is the first vice-dean of the faculty LCS (Languages, cultures and societies) of the University of Lille. She obtained her PhD in Finance in 2005 after a Master in Financial Engineering from the Institut d'Administration des Entreprises. She also holds a Master's degree in Business Law and the Certificate of Lawyer's Professional Skill. Since its creation in 2009, she has been the Director of the "Master Langues Etrangères Appliquées Parcours Management de Projets Touristiques" (University of Lille). She has published in international and national academic conferences proceedings and in academic journals in the fields of tourism, banking, and energy related services. 